\begin{tabular}{|c|c|c|}
\hline \hline & $\begin{array}{c}\text { International Journal of Current Research in } \\
\text { Biosciences and Plant Biology }\end{array}$ \\
\hline EXCELLENT \\
PUBLISHERS
\end{tabular}

\title{
Detection of Salt Tolerant Rice Genotypes at the Seedling Stage Using Molecular Markers: A Genotypic Analysis
}

\author{
Samer Adnan Hani ${ }^{1}$, Selvam Arjunan ${ }^{2 *}$ and Radhakrishnan Senthilkumar ${ }^{1}$ \\ ${ }^{I}$ Department of Biotechnology, Indian academy Degree College, Hennur Cross, Bangalore-560 043, India \\ ${ }^{2}$ Department of Life Sciences, Kristu Jayanti College (Autonomous), K. Narayanapura, Kothanur P.O., Bangalore-560 077, India
}

*Corresponding author.

\begin{tabular}{|c|c|}
\hline Abstract & Article Info \\
\hline $\begin{array}{l}\text { Selection of salinity tolerant genotypes of rice based on the phenotypic variation is not } \\
\text { consistent and thereby, will hinder the advancement in breeding. However, the recent }\end{array}$ & $\begin{array}{l}\text { Accepted: 04 March } 2017 \\
\text { Available Online: } 06 \text { March } 2017\end{array}$ \\
\hline $\begin{array}{l}\text { (SSRs) to detect the salt tolerant rice genotypes is reliable. The objective of the present } \\
\text { study was to screen the four indigenous rice genotypes collected at Coastal Saline }\end{array}$ & Keywords \\
\hline $\begin{array}{l}\text { Research Centre, Ramanathapuram, Tamil Nadu, India, under saline and non-saline } \\
\text { conditions using the microsatellite markers for the identification of salt tolerant genotypes } \\
\text { at the seedling and reproductive stages. Two selected SSR markers were used to determine } \\
\text { salinity tolerance in rice genotypes. SSR based marker identified three genotypes as } \\
\text { tolerant at least tolerant to one of the two SOS markers but one variety was susceptible for } \\
\text { both the markers. The detected salt tolerant genotypes can be a probable germplasm } \\
\text { resource for prospective breeding program. }\end{array}$ & $\begin{array}{l}\text { Na+/K+ ratio, } \\
\text { SOS genes } \\
\text { Salt stress } \\
\text { SSR markers } \\
\text { RM315 markers }\end{array}$ \\
\hline
\end{tabular}

\section{Introduction}

Salinity, which is considered as a severe limitation to increase the production of rice worldwide, is one of the leading soil problems in rice growing countries followed by drought (Gregorio et al., 1997). It has also been well recognized that salt tolerance varies with rice (Habib et al., 2013). Salinity affects the growth and development of the rice plant owing to the abiotic stress on the plants directly (Arshad et al., 2012). Salt stress, which has been shown to cause osmotic stress, ionic toxicity, oxidative stress and nutritional imbalance in plants, affects the germination and seedling growth of the plant. It also decreases the leaf expansion which leads to diminished photosynthetic area and dry matter production (Ashraf, 2010).

In India, rice (Oryza sativa), one of the most important staple food, cultivated in about 42.2 million hectares of the total arable land area of 148 million hectares, yielded an average of 2.12 metric tons per hectare (Manjunatha, 2009). Abiotic stress, a key hazard to crop production worldwide, negatively affects the mean yield of major crops by greater than $50 \%$ (Boyer, 1982). It has been estimated that the total area which is under salinity is 953 million hectares and it accounts for only $8 \%$ of the total land surface. Consequently, coastal areas are predominantly susceptible to salinity owing to the saline water intrusion as well as the 
increase in sea level due to the global warming (Amirjani, 2010).

Although rice is comparatively tolerant to salinity at the germination stage, its panicle initiation and pollination stage are sensitive to salinity and as a result, it is directly associated with crop yield (Heenan et al., 1988; Khatun and Flowers, 1995; Zhang et al., 2001). Moreover, screening of rice genotypes at seedling stage is relatively easier than reproductive stage and also rapid but it is very complex at the reproductive stage (Gregorio et al., 1997). Other than the reproductive stage of the rice plant, environmental and less sense heritability of salt tolerance also affect the salt tolerance of the plant (Gregorio, 1997).

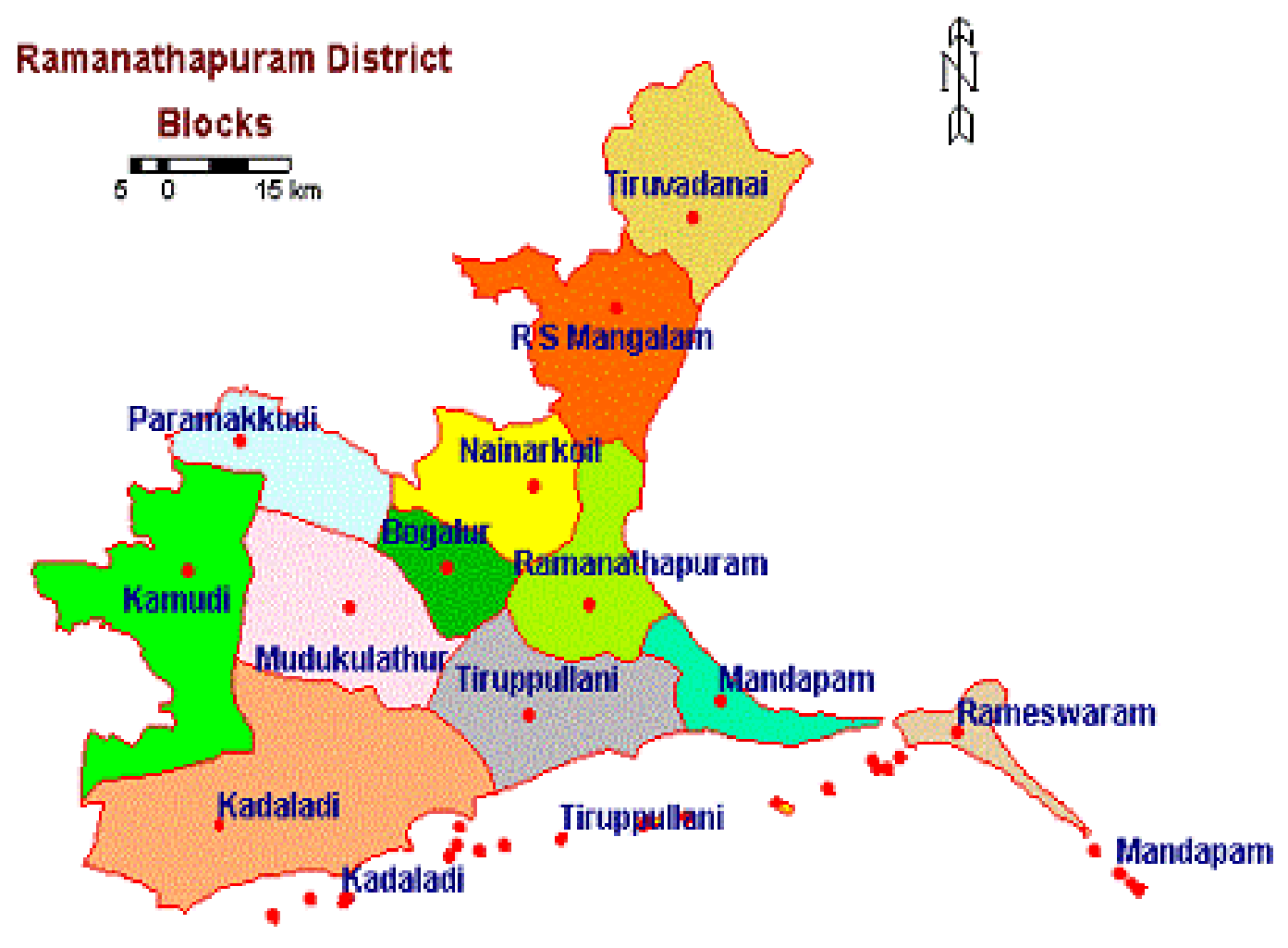

Fig. 1: Collection of indigenous rice varieties from Ramanathapuram District, Tamil Nadu, India.

It has been found that the detection of a major gene locus for salt tolerance next to a microsatellite marker can be used by plant breeders to select more efficiently and to better understand salt tolerance, at vegetative and reproductive growth stages. SSR or microsatellite markers, which are found to be principle model for constructing genetic maps (Niones, 2004), support selection and studying genetic diversity in genotype, play an important role in detecting the gene for salt tolerance and thereby, it can be useful for plant breeders to develop new cultivars. In the light of the above findings, the aim of the present study was to screen the four indigenous rice genotypes collected at Coastal Saline Research Centre, Ramanathapuram (Fig.1), under saline and non-saline conditions using the microsatellite markers for the identification of salt tolerant genotypes at the seedling and reproductive stage.

\section{Materials and methods}

\section{Collection of indigenous rice varieties}

Rice samples were collected from Ramanathapuram district in Tamil Nadu, India, which is located in the southern part of the state lying in the latitude between $9^{\circ} .05^{\prime}$ and $9^{\circ} .50^{\prime}$ in North and longitude between $78^{\circ} .10^{\prime}$ and $79^{\circ} .27^{\prime}$ in East. The district has a hot tropical climate with temperature ranging between $22.3^{\circ}-37.8^{\circ} \mathrm{C}$ and very high relative humidity ranging from $80-90 \%$ in coastal tracts. The rainfall distribution of Ramanathapuram district is very uneven and is less than $870 \mathrm{~mm}$ per annum. Paddy is being cultivated in rain fed conditions. Observations over the past 20 years clearly indicated that the North East Monsoon in this district commences by the third week of October and is prevalent till December. Due 
to high intensity of rainfall during this season water stagnation becomes a common problem for the cultivation of irrigated dry crops. This restricts the farmers to take up only paddy as a mono crop under the water stagnant conditions. After the harvest of the rice crop, the entire cultivable area is barren or kept vacant either due to shortage of water or non suitability of underground water which is saline in nature.

Another important reason for the low crop productivity or crop failure in this district is the poor quality of ground water with more chlorine content and EC which ranges from 4.0-12.0 due to sea water intrusion. The sea water intrusion has already extended up to $50 \mathrm{~km}$ from the coastal zone and in future it is likely to extend further. Based on this, one can presume that the crop cultivation in Ramanathapuram district will have to depend only on saline water. The saline and alkaline condition is also found all over the district. The $\mathrm{pH}$ of soil ranges from 8.1 to 8.6 and the EC is more than 3.0 in most of the area. In our present study, four indigenous rice genotypes were collected with the help of the scientists working in Coastal Saline Research Centre, Ramanathapuram. Sample leaves from four indigenous paddies which is named as RMD 1 to 4, were collected at the early stage of rice crop cultivated in the coastal belt (14-16 day old). At each sampling, the three topmost fully expanded leaf positions were sampled from four hills per genotype. While a part of the samples were preserved in refrigerated condition another part was oven-dried $\left(70^{\circ} \mathrm{C}\right.$ to constant weight), ground and preserved as powder for further analysis.

\section{Analysis of sodium and potassium content from paddy leaf samples}

Ground and preserved powder was analyzed by flame photometry (Digital Flame Analyzer, Cole Parmer, Illinois, USA) for sodium and potassium content after $48 \mathrm{hrs}$ of extraction with $1 \mathrm{~N} \mathrm{HNO}_{3}$, following the procedure described by Yoshida et al. (1976). Briefly the leaves powders are first crushed by hand to make them into small crumbs in a plastic container, this operation is for the homogenization of the sample. Then the leaves are crushed by means of a micro-electric grinder so as to obtain a very fine grind. Care must be taken to clean the blade of the grinder with a brush after each grinding of sample to avoid mixing the samples and bias the results. After grinding of each sample, store vegetable stock powder in a pill box and write the name of the sample on the cap, this allows the stoker plant powder until analysis and mineralization.
The porcelain crucibles are weighed by the precision analytical balance with $1 \mathrm{~g}$ of plant powder for each sample corresponding to a number indicated on the porcelain crucible. For each sample three replications were performed. Once the weighing was carried out heating the contents of the crucibles on a hot plate, was done, at a temperature of $100^{\circ} \mathrm{C}$ for 10 minutes more or until powder black to grayish white. This is useful for smoke coming out at the beginning of the calcinations is given without using a furnace vent system. After placing the crucible in the furnace at a temperature of $470^{\circ} \mathrm{C}$ for $3 \mathrm{hrs}$ the output resulted in a grayish powder. Any movement of crucibles must be made by the special pliers to avoid breaking the crucibles and the burning of the fingers. Samples were allowed to cool then added to each crucible $20 \mathrm{~mL}$ of $1 \mathrm{~N}$ nitric acid $\mathrm{HNO}_{3}$. Then the samples were heated on a hotplate until boiling. Cooled and filtered through ashless filter paper and the filtrations were received in a $100 \mathrm{~mL}$ volumetric flask. Distilled water was added to the mark which is the mother solution. The determination of potassium and sodium in the flame spectrophotometer using stock solutions samples corresponding to each.

\section{Isolation of paddy leaf DNA}

DNA isolation was done from fresh leaf tissues of 14day old seedlings. DNA was extracted using the modified CTAB method. Grinding of leaf sample with extraction buffer and SDS was followed by incubating the leaf sap at $65^{\circ} \mathrm{C}$ for $10 \mathrm{~min} .100 \mu \mathrm{NaCl}$ and $100 \mu \mathrm{L}$ $\mathrm{CTAB}$ were added sequentially and mixed well; and incubated again at $65^{\circ} \mathrm{C}$ for 10 minutes. After that the suspensions were transferred to a new plate. $900 \mu \mathrm{L}$ chloroform: isoamyl (24:1) was added and mixed well by a shaker. The sample was then centrifuged at 5700 rpm for 10 minutes. After that the supernatant were transferred into new Eppendorf tubes. Then added $600 \mu \mathrm{L}$ ice-cold isopropanol and shaken slowly and then centrifuged at $5700 \mathrm{rpm}$ for 15 minutes. The supernatant was decanted and air dried for at least one hour. Pellets were washed with $70 \%$ ethanol $(200 \mu \mathrm{L})$, spanned for 15 minutes at $5700 \mathrm{rpm}$ and then air-dried for 1/2-1 hours. Then the ethanol was removed and air-dried. The pellets were resuspended in $30 \mu 11 \mathrm{X}$ TE buffer for further use.

\section{PCR amplification of the isolated DNA}

Amplification reactions were carried out in a thermal cycler with $25 \mu \mathrm{L}$ of PCR reaction mixture containing $2.5 \mu \mathrm{L}$ of $10 \mathrm{X}$ Taq-buffer, $1.0 \mu \mathrm{L}$ of $50 \mathrm{mM} \mathrm{MgCl}_{2}$ 
solution, $0.25 \mu \mathrm{L}$ of $2.5 \mathrm{mM}$ dNTPs mixture, and $1.0 \mu \mathrm{L}$ of each of the forward and reverse rice microsatellite primer (RM8094) and the primer for SOS genes at a concentration of $10 \mathrm{pmole} / \mu \mathrm{L}, 0.1 \mu \mathrm{L}$ (1unit) of $5 \mathrm{unit} / \mu \mathrm{L}$ Taq-DNA polymerase, $4 \mu \mathrm{L}$ of purified genomic DNA (100ng), and $15.15 \mu \mathrm{L}$ of PCR grade water. The primer used in this study was RM315; a rice-microsatellite (RM) marker, tightly linked with a drought tolerant QTL, located on the rice 1st chromosome was obtained from Integrated DNA Technologies, USA.

The other PCR reagents were obtained from Fermentus Life Science, USA. The thermal cycling conditions for the first cycle were $97^{\circ} \mathrm{C}$ for $5 \mathrm{~min}$ and $55^{\circ} \mathrm{C}$ for $2 \mathrm{~min}$. For the next 35 cycles, the temperature regime was $95^{\circ} \mathrm{C}$ for $1 \mathrm{~min}, 55^{\circ} \mathrm{C}$ for $1 \mathrm{~min}$, and $72^{\circ} \mathrm{C}$ for $2 \mathrm{~min}$. The final extension was at $72^{\circ} \mathrm{C}$ for $10 \mathrm{~min}$. The amplified products were resolved in native polyacrylamide gel (6\%) following the protocol given by Sambrook and Russel (2001) and documented in a gel documentation system (Perkin Elmer, Geliance 200 imaging system). The length of the amplified DNA bands (microsatellite alleles) were determined with reference to the $100 \mathrm{bp}$ DNA ladder (Fermentus Life Sci. USA) included in the gel as a size marker. The molecular weight (nucleotide base pairs) of the most intensely amplified bands for each microsatellite marker was analyzed using the Gel Doc software.

\section{Results and discussion}

Analysis of Paddy leaf samples for sodium and potassium content was carried out by flame photometry and the results are tabulated in Table 1.

Table 1. Na+/K+ ratio in the leaves of Indigenous Rice varieties.

\begin{tabular}{llll}
\hline Variety & Na ug/g & K ug/g & Na+/K+ ratio \\
\hline RMD-1 & 1.60 & 8.00 & 0.2 \\
RMD-2 & 2.80 & 2.00 & 1.4 \\
RMD-3 & 3.10 & 1.58 & 1.9 \\
RMD-4 & 7.80 & 1.90 & 4.1 \\
\hline
\end{tabular}

The variety (Table 1) RMD 1 showed very low $\mathrm{Na}+\mathrm{K}+$ ratio which may be an indication that this variety shows saline tolerance when compared with all other varieties. This is in line with the findings of Mishra et al., 1997. This low $\mathrm{Na}+\mathrm{K}+$ ratio of ion uptake is positively correlated with a high level of salt tolerance and can be taken into consideration as a desired characteristic while screening rice lines.
All the four varieties showed the genomic DNA was isolated as shown in the Fig. 2 and amplification for RM 315 marker which is an indication that all the four verities have general tendency for salt tolerance as shown in the Fig. 3. But in case of the SOS genes (SOS1 and SOS2) the variety RMD1 showed the presence for both. Surprisingly the same variety (which was later identified as Kalarpalai by seed enthusiast later) has very low $\mathrm{Na}+\mathrm{K}+$ ratio. This corroborated the property of RMD1 for saline resistance.

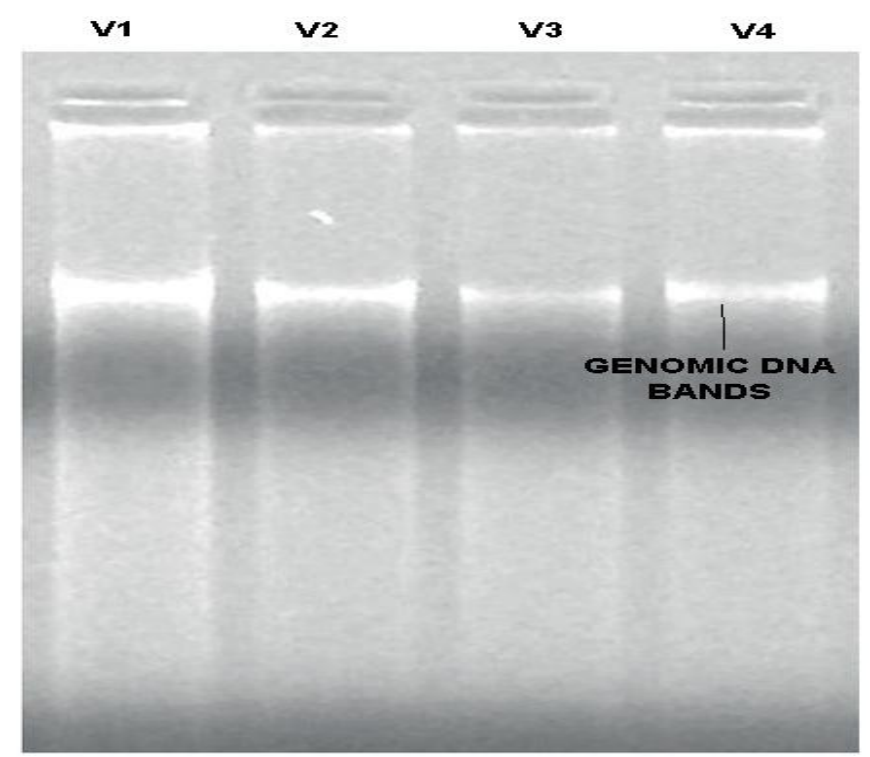

Fig. 2: Genomic DNA from Rice Leaves [Variety 1 (V1), Variety 2 (V2), Variety 3 (V3), Variety 4 (V4)].

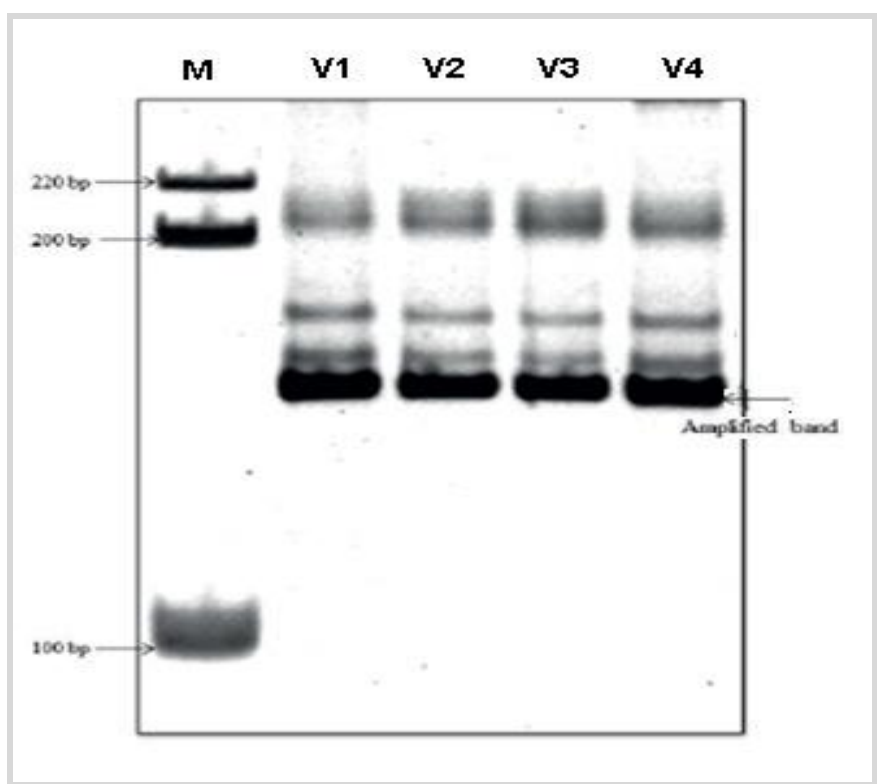

Fig. 3: DNA bands amplified from leaves of Rice genotypes V1, V2, V3 and V4 using microsatellite RM 315 marker. 

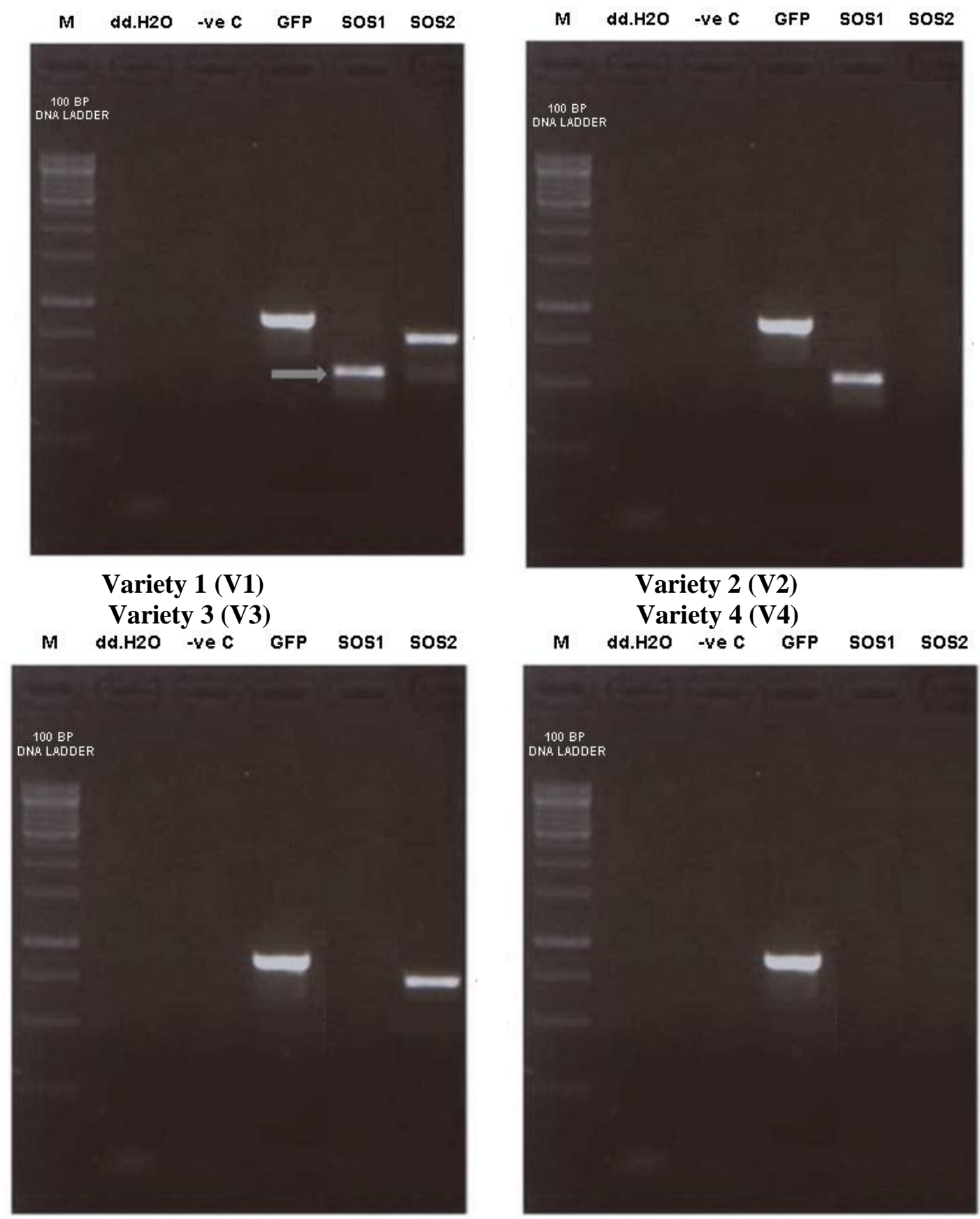

Fig. 4: The SOS GENES responsible for salt tolerance in rice plants.

Interestingly though all the four verities showed the presence of RM 315 marker, the RMD2 variety did not respond for SOS2 gene but responded positively for SOS1 gene (Fig. 4). The response of RMD3 is reverse in comparison to RMD2. RMD3 showed the presence of SOS2 gene. RMD2 and RMD3 verities showed 1.4 and $1.9 \mathrm{Na}+\mathrm{K}+$ ratio respectively as shown in the Table 1 . These values are higher than the value of RMD1. RMD4 did not respond for both SOS1 and SOS2. RMD4 also showed very high $\mathrm{Na}+/ \mathrm{K}+$ ratio.

The use of ionic composition in rice shoots or rice leaves as an indicator of performance under salinity has been argued controversially in recent years. Yeo and Flowers et al,. 1993, report that leaf sodium concentration in the seedling stage is closely related with survival, but shoot sodium concentration can only 
account for a small proportion of the variability in survival (Yeo et al., 1990). Qadar (1988) reports that the potassium status of the rice shoot can be used as an index for salt tolerance. Neither potassium nor sodium concentrations either in the shoot or in the leaves are sufficient as indicators for magnitude of yield loss due to salinity. Garcia et al. (1997) have recently shown that although, in rice, no significant relationship between shoot sodium and potassium concentrations exists, the sodium potassium ratio has narrow sense heritability. The leaf sodium concentration depends (among other factors) on the retention capacity for sodium in the leaf sheaths (Asch et al., 1997b). The relation between the two is an indicator for salt tolerance in rice as it captures both desirable high potassium uptake to the plant as a prerequisite for metabolic processes as well as osmotic adjustment and sodium as an indicator for the stress level.

This low $\mathrm{Na}+\mathrm{K}+$ ratio and the presence of $\mathrm{RM} 315$ markers along with SOS genes 1 and 2 positively correlated with a high level of salt tolerance and can be taken into consideration as a desired characteristic while screening rice lines. Molecular marker, which assists in detecting the alleles that are associated with major phenotypic variants, is found to be associated with salt tolerant alleles at seedling stage in rice using phenotypic and marker population. It is also known that salt stress genes were located at loci in chromosomes 1 and 8 . A study by Lang et al. (2000) also found that RM223, which is related to salt tolerance gene, is present in chromosome 8.

The results of the current study are in line with a study by Bhowmik (2009) which evaluated 11 rice genotypes using three SSR markers viz., RM7075, RM336 and RM253, found that markers were capable to distinguish the salt tolerant genotypes from the salt sensitive traits by exhibiting the polymorphism among them. The SSR markers including RM7075, RM336 and RM253 used detected 8, 9 and 7 salt tolerant genotypes, respectively.

\section{Conclusion}

As SSR or microsatellite markers are well known for constructing genetic maps, aiding in selection and studying genetic diversity in germplasms, they play a vital role in detecting salt tolerant gene to assist the plant breeder in developing new cultivars. Accordingly, these markers used in this study showed polymorphism for the rice genotypes. In addition, the detected salt tolerant rice genotypes can be considered as the potential source to improve the salt tolerant genotype.

\section{Conflict of interest statement}

Authors declare that they have no conflict of interest.

\section{References}

Amirjani, M.R., Effect of $\mathrm{NaCl}$ on some physiological parameters of rice. EJBS, 2010, vol. 3, pp. 6-16.

Arshad, M., M. Saqib, J. Akhtar and M. Asghar. 2012. Effect of calcium on the salt tolerance of different wheat (Triticum aestivum L.) genotypes. Pak. J. Agri. Sci., 49: 497-504.

Asch, F., M. Dingkuhn, M.S.C. Wopereis, K. Dörffling\& K. Miezan, 1997b. A conceptual model for sodium uptake and distribution in irrigated rice. In: M.J. Kropff et al. (Eds.), Applic-ations of Systems Approaches at the Field Level, pp. 201217, Kluwer Academic Publishers, Dordrecht.

Ashraf, M., Inducing drought tolerance in plants: some recent advances. Biotechnol. Adv. 2010, vol. 28, pp. 169-183.

Bhowmik, S. K., Titov, S., Islam, M. M., Siddika, A., Sultana, S., \&Haque, M. S. (2009). Phenotypic and genotypic screening of rice genotypes at seedling stage for salt tolerance. African Journal of Biotechnology, 8(23).

Boyer, J.S., Plant productivity and environment. Science, 1982, vol. 218, pp. 443-448.

Garcia, A., C.A. Rizzo, J. Ud-Din, S.L. Bartos, D. Senadhira, T.J. Flowers \& A.R. Yeo, 1997. Sodium and potassium transport to the xylem are inherited independently in rice, and the mechan-isms of sodium: potassium selectivity differs between rice and wheat. Plant Cell Env 20: 1167-1174.

Gregorio, G.B., Senadhira, D. and R.D. Mendoza. 1997. Screening rice for salinity tolerance. IRRI Discussion Paper Series no. 22. Manila (Philippines): International Rice Research Institute. pp.1-30.

Habib, N., M. Ashraf and M. Shahbaz. 2013. Effect of exogenously applied nitric oxide on some key physiological attributes of rice (Oryza sativa L.) plants under salt stress. Pak, J. Bot., 45(5): 15631569

Heenan, D.P., L.G. Lewin\& D.W. McCaffery, 1988. Salinity toler-ance in rice varieties at different growth stages. Aust J ExpAgr 28: 343-349.

Sambrook, J., Russell, D. W., 2001. Molecular cloning: 
a laboratory manual ??.

Khatun, S. \& T.J. Flowers, 1995. Effects of salinity on seed set in rice. Plant, Cell Environ. 18, 61-67.

Lang NT, Yanagihara S, Buu BC 2000. Quantitative trait loci for salt tolerance in rice via molecular markers. Omonrice 8:37-48.

Manjunatha, M.V., Masthnareddy, B.G., Shashidhar, S.G., and Joshi, V.R., Field performance evaluation of vertical conveyer paddy reaper. Karnataka J.Agric.Sci. 2009, vol. 22, pp. 140-142.

Mishra, B., R.K. Singh and D. Senadhira. 1997. Enhancing genetic resources and breeding for problem soils.International Development Research Centre, Ottawa, Canada.

Niones JM 2004. Fine mapping of the salinity tolerance gene on chromosome 1 of rice (Oryza sativa L.) using near isogenic lines. MS dissertation. College, Laguna, Philippines: University of the Philippines Los Baños, Laguna.
Qadar, A., 1988. Potassium status of the rice shoot as Index for salt tolerance. Ind J Plant Physiol 31: 388393.

Yeo, A.R. \& T.J. Flowers, 1993. Varietal differences in the toxicity of sodium ions in rice leaves. Physiol Plant 59: 189-195.

Yeo, A.R., M.E. Yeo, S.A. Flowers \& T.J. Flowers, 1990. Screening of rice (Oryza sativa L.) genotypes for physiological characters contributing to salinity resistance and their relationship to overall performance. TheorAppl Genet 79: 377-384.

Yoshida, S., D.A. Forno, J.H. Cock \& K.A. Gomez, 1976. Labor-atory manual for physiological studies of rice. International Rice Research Institute (IRRI), Manila, Philippines.

Zhang H-X, Blumwald E. 2001. Transgenic salt-tolerant tomato plants accumulate salt in foliage but not in fruit. Nature Biotechnology 19: 765-768.

\section{How to cite this article:}

Hani, S. A., Arjunan, S., Senthilkumar, R., 2017. Detection of salt tolerant rice genotypes at the seedling stage using molecular markers: A genotypic analysis. Int. J. Curr. Res. Biosci. Plant Biol. 4(3), 81-87. doi: https://doi.org/10.20546/ijcrbp.2017.403.009 